\title{
Advanced Test Method of Solid Oxide Cells in a Plug-Flow Setup
}

\author{
Jensen, Søren Højgaard; Hauch, Anne; Hendriksen, Peter Vang; Mogensen, Mogens Bjerg
}

Published in:

Journal of The Electrochemical Society

Link to article, DOI:

10.1149/1.3116247

Publication date:

2009

Document Version

Publisher's PDF, also known as Version of record

Link back to DTU Orbit

Citation (APA):

Jensen, S. H., Hauch, A., Hendriksen, P. V., \& Mogensen, M. B. (2009). Advanced Test Method of Solid Oxide Cells in a Plug-Flow Setup. Journal of The Electrochemical Society, 156(6), B757-B764.

https://doi.org/10.1149/1.3116247

\section{General rights}

Copyright and moral rights for the publications made accessible in the public portal are retained by the authors and/or other copyright owners and it is a condition of accessing publications that users recognise and abide by the legal requirements associated with these rights.

- Users may download and print one copy of any publication from the public portal for the purpose of private study or research.

- You may not further distribute the material or use it for any profit-making activity or commercial gain

- You may freely distribute the URL identifying the publication in the public portal 


\title{
Advanced Test Method of Solid Oxide Cells in a Plug-Flow Setup
}

\author{
Søren Højgaard Jensen, ${ }^{*, z}$ Anne Hauch, \\ Peter Vang Hendriksen, and Mogens Mogensen*
}

Fuel Cells and Solid State Chemistry Division, Risф National Laboratory for Sustainable Energy, Technical University of Denmark, DK-4000 Roskilde, Denmark

\begin{abstract}
This paper describes a case study of two electrolysis tests of solid oxide cells [Ni/yttria-stabilized zirconia (YSZ)-YSZ-lanthanum strontium manganite (LSM)/YSZ] tested in a plug-flow setup. An extensively instrumented cell test setup was used, and the tests involved measurements of the cell impedance at open-circuit voltage and under current load, the cell voltage, and the in-plane voltage in the electrodes. From the cell-voltage measurements it was evident that a significant passivation of the cells occurred over the first $\sim 10$ days. Thereafter, the cells reactivated at constant electrolysis conditions. From measurements of the in-plane voltages in the electrodes and impedance spectra obtained during the electrolysis operation, we derive information about the resistance distributions in the Ni electrodes and describe how these distributions evolve over time. Impedance spectra at opencircuit voltage before and after electrolysis testing at various gas compositions were used to show that the Ni electrode was affected by the electrolysis operation, whereas the LSM electrode was not.

(C) 2009 The Electrochemical Society. [DOI: 10.1149/1.3116247] All rights reserved.
\end{abstract}

Manuscript submitted January 28, 2009; revised manuscript received March 12, 2009. Published April 21, 2009.

Over the last couple of decades there has been extensive research and development of solid oxide fuel cells (SOFCs) which has led to significant improvements in cell performance ${ }^{1-7}$ and durability of SOFCs. ${ }^{7-9}$ Furthermore, there is a renewed and increased interest in the reversibility of solid oxide cells (SOCs); that is, using them as solid oxide electrolysis cells (SOECs) for steam or carbon dioxide electrolysis. ${ }^{10-21}$

In recent years, the SOC technology has moved toward a commercial breakthrough, and the research and development work now also includes aspects such as inexpensive processing techniques, stack and system development, and upscaling of cell production. ${ }^{9,22,23}$ From the technological and commercial point of view, the long-term stability (over years) of the cells is a critical issue, and long-term full cell testing is thus important in order to analyze, characterize, and subsequently control the processes detrimental to the stability of the cells.

Testing of full cells is complex due to both the many components (electrodes, electrolyte, support layers, barrier layers, auxiliary components) ${ }^{6}$ and the inhomogenities (in resistances, temperatures, etc.) across a cell that is typically several centimeters long and wide. $^{24}$ The complexity of full cell testing and the need to understand the processes leading to losses in performance for such technologically relevant cells makes it necessary to use an advanced cell test setup with extensive instrumentation. To assist in such investigations of losses in performance for full cells, we describe a test setup and method which provide detailed information about the passivation mechanisms in the cell during operation. It involves the recording of electrochemical impedance spectra (EIS) at opencircuit voltage (OCV) at various gas compositions before and after test under current load, monitoring of the cell voltage and in-plane voltages along the electrodes during testing, and regularly recording of EIS under current load. Cell-voltage measurements and EIS are performance measures for the entire cell. The EIS can reveal which processes are dominating in the passivation of the cell ${ }^{25-30}$ and can be used to give a characteristic of each electrode when various gas compositions are applied. ${ }^{31}$ In contrast, the in-plane measurements provide information on voltage differences across the electrode and can reveal unevenness in the current and resistance distribution over the electrode.

This work is a case study showing the tests of two SOCs used as SOECs for steam electrolysis. Previously we have reported on the initial performance and durability for such SOECs and described problems with impurities in the Ni electrode. ${ }^{1732-34}$ In this case

\footnotetext{
Electrochemical Society Active Member.
}

z E-mail: soeren.hoejgaard.jensen@ risoe.dk study, we use similar cells for electrolysis testing as previously reported; however, the focus is on how the description and use of an extensively instrumented test setup for cell testing in plug-flow can provide the data necessary for a thorough characterization of the cells and analysis of the process(es) leading to the loss in performance. The data analyses for the two tests in this study show that it is mainly changes in the Ni electrode that lead to the loss in performance for the SOECs.

\section{Experimental}

Cell specifications. - The tested cells are hydrogen-electrodesupported SOFCs produced at Ris $\emptyset$ National Laboratory for Sustainable Energy. ${ }^{8,35}$ The cells have a $10-15 \mu \mathrm{m}$ thick hydrogen electrode of Ni/yttria-stabilized zirconia (YSZ) cermet and are supported by a $\sim 300 \mu \mathrm{m}$ thick Ni/YSZ layer. Moreover, the cells have a $10-15 \mu \mathrm{m}$ thick YSZ electrolyte and a 15-20 $\mu \mathrm{m}$ thick lanthanum strontium manganite (LSM)-YSZ composite oxygen electrode. ${ }^{35}$ The planar SOCs have an active electrode area of $4 \times 4 \mathrm{~cm}^{2}$.

Test procedure.- We show results from electrolysis testing of two cells, referred to as test $\mathrm{A}$ and $\mathrm{B}$. "Test" $\mathrm{A}_{\mathrm{EL}}$ and $\mathrm{B}_{\mathrm{EL}}$ refer to test periods at which they were operated at constant electrolysis conditions. The overall test sequence was similar for both cells and is illustrated in Fig. 1. First, the cells were heated to $1000^{\circ} \mathrm{C}$ in order to soften the seal and to reduce the $\mathrm{NiO}$ in the $\mathrm{Ni}$ electrode by purging $\mathrm{H}_{2}$ to the electrode. Then, the temperature was lowered to $750^{\circ} \mathrm{C}$, and the cells were characterized by recording current density-voltage curves and a series of EIS applying different gas compositions. After this characterization, the cells were heated to $850^{\circ} \mathrm{C}$ and characterized again before the electrolysis operation was initiated. Finally, after $\mathrm{A}_{\mathrm{EL}}$ and $\mathrm{B}_{\mathrm{EL}}$, the cell characterization was repeated at 850 and $750^{\circ} \mathrm{C}$.

Impedance spectroscopy.- All the EIS presented here were recorded using a Solartron 1260 frequency analyzer with six points per frequency decade and an ac current density of $3.75 \mathrm{~mA} / \mathrm{cm}^{2}$ EIS were recorded at OCV before and after electrolysis testing but also during electrolysis operation. In order to measure the cell im-

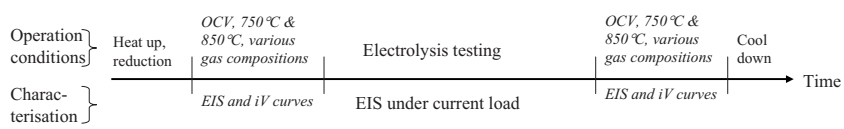

Figure 1. Timeline for characterization and electrolysis testing of two SOCs Italic text describes initial and end characterization of the cells at OCV. 
a)

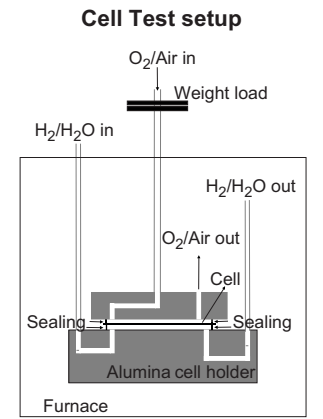

C) Gas distribution and sealing

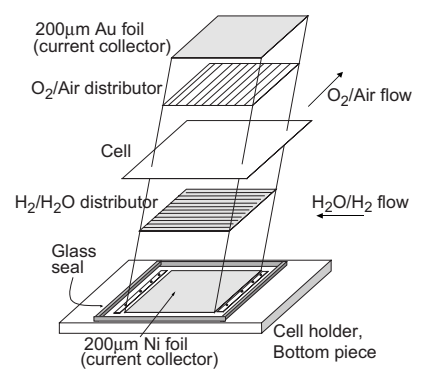

Figure 2. Cell test setup. (a) The cell is placed between two alumina cell holders. Albite glass seals prevent gas mixing. (b) The cell holders shown with holes for Pt wires for current pickup and probing. Gas to the electrodes enters and exits through ditches adjacent to the electrodes. (c) Currentcollector foils, gas-distribution layers, and the cell are sandwiched between the two cell holders.

pedance during dc load, a setup was used where the ac current in the cell was measured in a shunt in series with the cell as described elsewhere. $^{36}$

Test set-up specifications.-Figure 2 shows drawings of the cell test setup. Figure $2 \mathrm{a}$ is a drawing of a cross section of the cell test setup. The cell was held between two alumina blocks in which gassupply channels and holes for Pt wires for current pick-up and voltage probing were fabricated. (The holes for Pt wires are not shown.) Albite $\left(\mathrm{NaAlSi}_{3} \mathrm{O}_{8}\right)$ glass seals were used for these tests to prevent gas mixing. Figure $2 \mathrm{~b}$ illustrates the alumina cell test house and positions of holes for Pt wires for current pick-up and voltage probing. The four voltage probes were used to monitor the cell voltage and the in-plane voltage along the electrodes. The cell voltage was measured between probes 1 and 3. The LSM-electrode in-plane voltage was measured between probes 1 and 2 , and the $\mathrm{Ni}$ electrode in-plane voltage was measured between probes 3 and 4. Any inplane voltage (and current) indicates an uneven distribution of the current across the electrodes. Based on the compositions and thicknesses of the different layers (Fig. 2c), the in-plane resistance at the $\mathrm{Ni}$-electrode side was estimated to be $\sim 1.5 \mathrm{~m} \Omega$ and the in-plane resistance at the LSM electrode side to be $\sim 0.5 \mathrm{~m} \Omega$. These two in-plane resistances are estimated values for the resistance in the $\mathrm{Ni}$ current-collector foil between points 1 and 2 and the resistance in the gold current-collector foil between points 3 and 4, respectively. Hence, by logging the in-plane voltages, it was possible to obtain a measure of the in-plane currents over time. In the two tests presented in this paper, the in-plane current never went higher than $10 \%$ of the total current through the cell.

Figure 2c shows how the cell is "sandwiched" between two channelled gas-distributor plates and two current-collector foils. The plates and foils are all $4 \times 4 \mathrm{~cm}^{2}$. The foils are $0.2 \mathrm{~mm}$ thick, and the plates are ca. $1 \mathrm{~mm}$ thick. The Ni-electrode gas-distributor layer is made of Ni/YSZ, and the LSM-electrode gas-distributor layer is made of LSM/YSZ. The wires for voltage probing and current a)

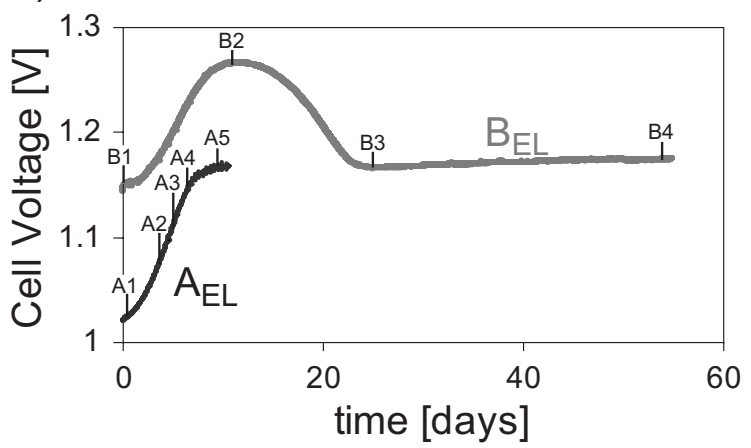

b)

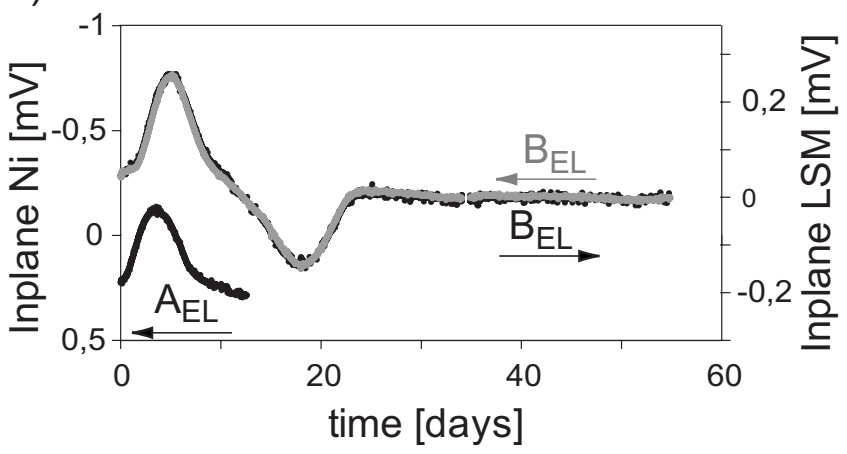

Figure 3. (a) Cell voltage vs time for tests $A_{E L}$ and $B_{E L}$. (b) In-plane voltages vs time for tests $\mathrm{A}_{\mathrm{EL}}$ and $\mathrm{B}_{\mathrm{EL}}$. The LSM in-plane voltage was not recorded in tests $\mathrm{A}_{\mathrm{EL}}$. Both tests $\mathrm{A}_{\mathrm{EL}}$ and $\mathrm{B}_{\mathrm{EL}}$ were operated at $850^{\circ} \mathrm{C}$ and with a current density of $-0.5 \mathrm{~A} / \mathrm{cm}^{2}$. The operating conditions are further specified in Table I.

pick-up (Fig. 2b) contact the current-collector foils. Gas entered and exited the electrodes through ditches at each side of the electrodes. The seal assured that the electrode gas did not escape to the oven chamber but instead was distributed to the electrodes via the gasdistribution layers. Note that the gas flow was a cross flow.

\section{Data acquisition}

Data, such as temperatures $\left(T_{\text {cell center }}, T_{\text {cell corner }}, T_{\text {furnace, }}\right.$ gas inlet and outlet temperatures, etc.), voltages (cell voltage, in-plane voltages, and oxygen potentials vs air in inlet and outlet gasses), and gas flows, was logged automatically. Data was logged every $10 \mathrm{~min}$. The scatter of the cell voltage was less than $1 \mathrm{mV}$ (indicating low fluctuations of the steam supply), and the cell temperature fluctuations was less than $1{ }^{\circ} \mathrm{C} .^{37}$

\section{Results}

Cell voltage and in-plane voltage measurements during electrolysis testing. - Both the cell voltage and the in-plane voltages changed over time during electrolysis testing for tests $\mathrm{A}_{\mathrm{EL}}$ and $\mathrm{B}_{\mathrm{EL}}$. Figure 3a shows the cell voltages as a function of time during galvanostatic electrolysis testing $\left(-0.5 \mathrm{~A} / \mathrm{cm}^{2}\right)$, and Fig. $3 \mathrm{~b}$ shows the in-plane voltages as a function of time. The in-plane voltage was not recorded on the LSM-electrode side in test $\mathrm{A}_{\mathrm{EL}}$. Table I gives an overview of the electrolysis test conditions. Note how the evolution of the in-plane voltages on the Ni-electrode side is alike for tests $\mathrm{A}_{\mathrm{EL}}$ and $\mathrm{B}_{\mathrm{EL}}$. In Fig. 3b, an off-set of $0.05 \mathrm{mV}$ was subtracted from the LSM in-plane voltage to better illustrate the strong correlation between the measured $\mathrm{Ni}$ and LSM in-plane voltages for test $\mathrm{B}_{\mathrm{EL}}$.

Comparing the development of the cell voltages (Fig. 3a) with the development of the in-plane voltages (Fig. 3b) for the two electrolysis tests, it is evident that the in-plane voltages reach extreme values approximately when the slope of the tangent for the increas- 


\begin{tabular}{|c|c|c|c|}
\hline \multirow[b]{2}{*}{ Test } & \multicolumn{2}{|c|}{$\mathrm{H}_{2} / \mathrm{H}_{2} \mathrm{O}$ gas flow } & \multirow[b]{2}{*}{ Steam conversion } \\
\hline & Purge rate $(\mathrm{L} / \mathrm{h})$ & $\mathrm{H}_{2} \mathrm{O}$ content $(\mathrm{vol} \%)$ & \\
\hline $\mathrm{A}_{\mathrm{EL}}$ & 12 & 99 & $28 \%$ \\
\hline $\mathrm{B}_{\mathrm{EL}}$ & 25 & 50 & $28 \%$ \\
\hline
\end{tabular}

ing cell voltage is at a maximum. The in-plane voltages return to their initial values approximately at the time when the cell voltages are at a maximum, e.g., where the total loss in performance for the cells is at a maximum.

Furthermore, the in-plane voltages for test $\mathrm{B}_{\mathrm{EL}}$ reach extreme values at the time when the tangent for the decreasing cell voltage is at a maximum (between points B2 and B3 in Fig. 3a). Test $\mathrm{A}_{\mathrm{EL}}$ was not operated long enough at constant electrolysis conditions to see a possible activation (decreasing cell voltage) as observed for test $\mathrm{B}_{\mathrm{EL}}$.

EIS during electrolysis testing.- EIS were recorded on a daily basis for the two tests. Figure 4 shows some selected EIS, and the marking [A1...A5] and [B1...B4] correspond to the time marks given in Fig. 3a. From the EIS in Fig. 4, it can be observed that series resistance (the real part of the impedance at the highest measurement frequency) remains almost constant in both tests $\mathrm{A}_{\mathrm{EL}}$ and $\mathrm{B}_{\mathrm{EL}}$, whereas the polarization resistances change significantly during electrolysis testing. In test $\mathrm{B}_{\mathrm{EL}}$, the polarization resistance increases with time and subsequently decreases almost to its initial value, and the polarization resistance for test $\mathrm{B}_{\mathrm{EL}}$ follows the trend of the cell voltage in Fig. 3a. The larger series resistance in test B compared with test $\mathrm{A}$ is due to a minor contact problem associated with the current-collector foil.

As seen in Fig. 4 (especially in Fig. 4a), the magnitude of the low-frequency arc varies with time. However, the summit frequency, $f_{\mathrm{s}}$, (the frequency at the top of the arc) stays constant for the lowfrequency arc in the EIS. $f_{\mathrm{s}}$ for the low-frequency $\operatorname{arc}$ is $1 \mathrm{~Hz}$ in test $\mathrm{A}_{\mathrm{EL}}$ and $4 \mathrm{~Hz}$ in test $\mathrm{B}_{\mathrm{EL}}$.

\section{a)}

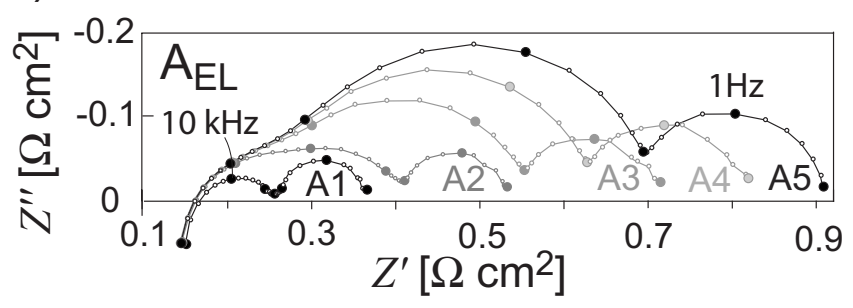

b)

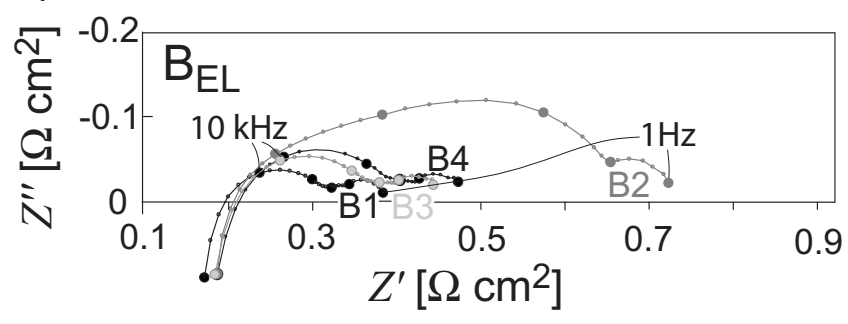

Figure 4. EIS during tests $A_{E L}$ and $B_{E L}$ : (a) EIS [A1...A5] recorded during test $\mathrm{A}_{\mathrm{EL}}$. (b) EIS [B1...B4] recorded during test $\mathrm{B}_{\mathrm{EL}}$. Time marks for the spectra $[\mathrm{A} 1 \ldots \mathrm{A} 5]$ and $[\mathrm{B} 1 \ldots \mathrm{B} 4]$ are shown in Fig. 3. The bold points mark the frequency decades $(82 \mathrm{kHz}$ to $0.82 \mathrm{~Hz})$. Operating conditions during tests $\mathrm{A}_{\mathrm{EL}}$ and $\mathrm{B}_{\mathrm{EL}}$ are given in Table I.

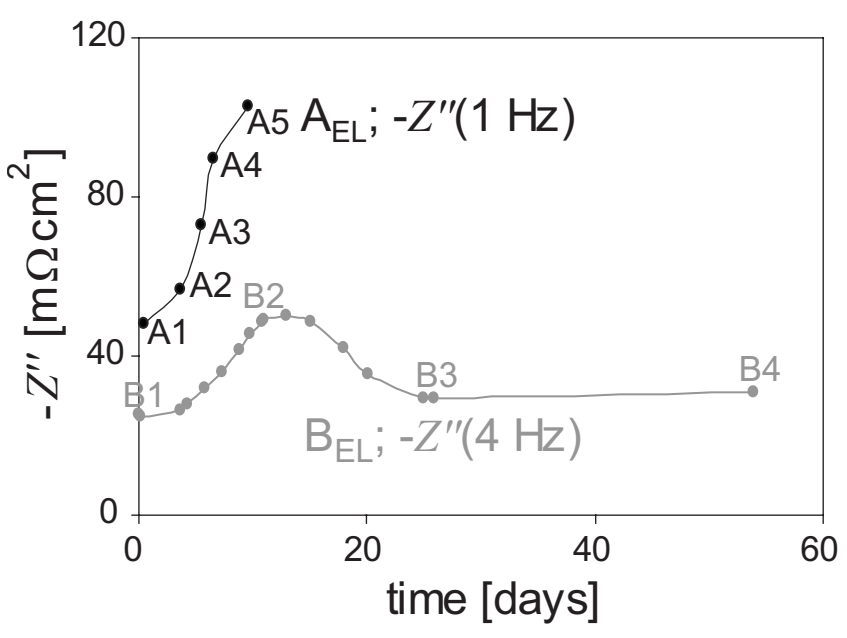

Figure 5. $-Z^{\prime \prime}\left(f_{\mathrm{s}}\right)$ vs time for the low-frequency arc of the spectra in Fig. 4. $-Z^{\prime \prime}\left(f_{\mathrm{s}}\right)$ vs time resembles the trend of the cell voltage vs time in Fig. 3a. Operating conditions are presented in Table I.

Figure 5 shows a plot of the imaginary part of the impedance, that is, $-Z^{\prime \prime}(1 \mathrm{~Hz})$, vs time for test $\mathrm{A}_{\mathrm{EL}}$ and $-Z^{\prime \prime}(4 \mathrm{~Hz})$ vs time for test $\mathrm{B}_{\mathrm{EL}}$. This clearly shows how the magnitudes of the lowfrequency arc evolve with time. From Fig. 5 it is evident that the trend for the magnitude of the low-frequency arc of the EIS resembles that of the cell voltages in Fig. 3a.

EIS at OCV before and after electrolysis testing.- As stated in the Experimental section, EIS were recorded at OCV before and after electrolysis tests $\mathrm{A}_{\mathrm{EL}}$ and $\mathrm{B}_{\mathrm{EL}}$ with various gas compositions at the electrodes to make electrode impedance characteristics. The EIS referred to in this paragraph are all recorded at $750^{\circ} \mathrm{C}$, because this temperature is superior to $850^{\circ} \mathrm{C}$ in terms of frequency resolution of the different arcs in the EIS. Tests $\mathrm{A}_{\mathrm{El}}$ and $\mathrm{B}_{\mathrm{El}}$ were operated at $850^{\circ} \mathrm{C}$ rather than at $750^{\circ} \mathrm{C}$ because the cell performance increases with temperature, making $850^{\circ} \mathrm{C}$ the preferred technological temperature. The EIS recorded before test $\mathrm{B}_{\mathrm{EL}}$ are shown in Fig. 6a, and the EIS recorded after test $\mathrm{B}_{\mathrm{EL}}$ are shown in Fig. 6b. The spectra

a)

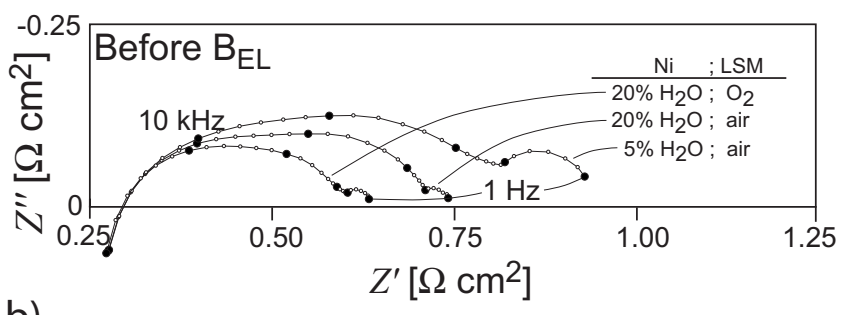

b)

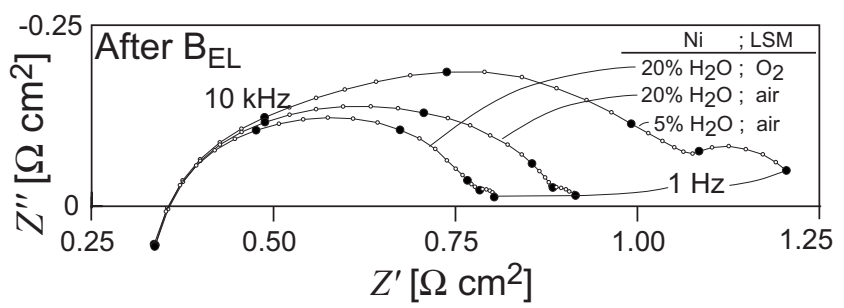

Figure 6. EIS recorded at $\mathrm{OCV}$ and $750^{\circ} \mathrm{C}$ at various gas compositions: (a) EIS recorded before test $\mathrm{B}_{\mathrm{EL}}$ and (b) EIS recorded after test $\mathrm{B}_{\mathrm{EL}}$. The spectra were recorded with $\mathrm{H}_{2}$ diluted with $\mathrm{H}_{2} \mathrm{O}$ purged to the Ni electrode and the molar $\mathrm{H}_{2} \mathrm{O}$ concentration for each spectrum is specified in the figure. At the same time, $\mathrm{O}_{2}$ or air was purged to the LSM electrode. 
a)

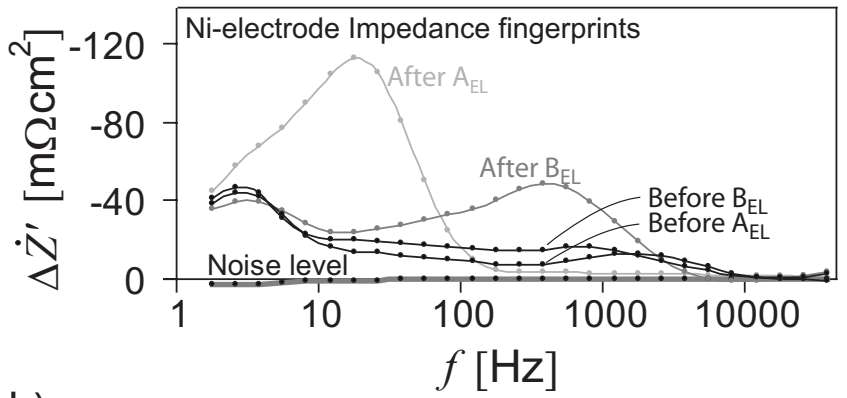

b)

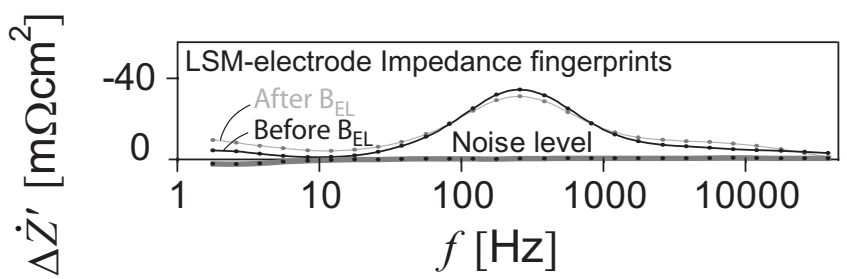

Figure 7. (a) Electrode impedance characteristics measured at $750^{\circ} \mathrm{C}$ for tests A and B based on EIS recorded at OCV before and after electrolysis testing (Fig. 6). (b) The overlap between the two LSM-electrode impedance characteristics before and after $\mathrm{B}_{\mathrm{EL}}$, which shows that test $\mathrm{B}_{\mathrm{EL}}$ did not affect the LSM electrode.

were recorded with $\mathrm{H}_{2} / \mathrm{H}_{2} \mathrm{O}$ purged to the $\mathrm{Ni}$ electrode at a rate of $25 \mathrm{~L} / \mathrm{h}$. Air or $\mathrm{O}_{2}$ was purged to the LSM electrode at either $140 \mathrm{~L} / \mathrm{h}$ (air) or $20 \mathrm{~L} / \mathrm{h}\left(\mathrm{O}_{2}\right)$. The exact gas composition to the electrodes is specified in Fig. 6 for each spectrum.

The impedance difference, $\Delta Z$, between the two EIS recorded before test $\mathrm{B}_{\mathrm{EL}}$ with air to the LSM electrode (Fig. 6a) is a result of the change in the gas composition at the $\mathrm{Ni}$ electrode. In particular, $\Delta Z$ contains no impedance contribution from the LSM electrode, i.e., this impedance difference solely reflects features of the Ni electrode. $\Delta Z$ may be visualized in many ways. We choose to plot $\Delta \dot{Z}^{\prime}$ vs $\log (f)$, because $\Delta \dot{Z}^{\prime}$ is fairly easy to obtain (see Eq. 1) and $\Delta \dot{Z}^{\prime}$ vs $\log (f)$ offers a reasonably good resolution of the individual impedance arcs. $^{31}$

The impedance, $Z$, is normally only measured at a finite set of frequencies $\left\{f_{1}, f_{2}, \ldots, f_{N}\right\}$, where $N$ denotes the number of frequencies, $f_{1}$ denotes the lowest measurement frequency, and $f_{\mathrm{N}}$ denotes the highest measurement frequency. For the $n$th frequency between 2 and $N-1, \Delta \dot{Z}^{\prime}$, the derivative with respect to $\ln (f)$ of the real part of $\Delta Z$, can be obtained as

$$
\Delta \dot{Z}^{\prime}\left(f_{\mathrm{n}}\right) \cong \frac{\left[Z^{\prime}\left(f_{\mathrm{n}+1}\right)-Z^{\prime}\left(f_{\mathrm{n}-1}\right)\right]_{\varphi}-\left[Z^{\prime}\left(f_{\mathrm{n}+1}\right)-Z^{\prime}\left(f_{\mathrm{n}-1}\right)\right]_{\varphi^{*}}}{\ln \left(f_{\mathrm{n}+1} / \mathrm{Hz}\right)-\ln \left(f_{\mathrm{n}-1} / \mathrm{Hz}\right)}
$$

where $Z^{\prime}\left(f_{\mathrm{n}+1}\right)$ is the real part of $Z$ at the $\mathrm{n}+1$ measurement frequency and $\left[Z^{\prime}\left(f_{\mathrm{n}+1}\right)-Z^{\prime}\left(f_{\mathrm{n}-1}\right)\right]_{\varphi}$ is the difference between $Z^{\prime}\left(f_{\mathrm{n}+1}\right)$ and $Z^{\prime}\left(f_{\mathrm{n}-1}\right)$ measured at the operating condition $\varphi$. Referring to the two EIS recorded before test $\mathrm{B}_{\mathrm{EL}}$ with air to the LSM electrode (Fig. 6a), $\varphi$ denotes the operating conditions when recording the spectrum with $\mathrm{H}_{2}$ containing $20 \% \mathrm{H}_{2} \mathrm{O}$ to the Ni electrode, and $\varphi^{*}$ denotes the operating conditions when recording the spectrum with $\mathrm{H}_{2}$ containing $5 \% \mathrm{H}_{2} \mathrm{O}$. Still referring to the same two impedance spectra where only the $\mathrm{H}_{2} / \mathrm{H}_{2} \mathrm{O}$ ratio was changed, the plot of $\left\{\Delta \dot{Z}^{\prime}\left(f_{2}\right), \ldots, \Delta \dot{Z}^{\prime}\left(f_{N-1}\right)\right\}$ vs $\left\{\log \left(f_{2}\right), \ldots, \log \left(f_{N-1}\right)\right\}$, or in short, $\Delta \dot{Z}^{\prime}$ vs $\log (f)$, is a Ni-electrode impedance characteristic prior to the electrolysis testing $\mathrm{B}_{\mathrm{EL}}$. This Ni-electrode impedance characteristic for test B is shown in Fig. 7a.
In a similar manner, the two EIS in Fig. 6a recorded with $\mathrm{H}_{2}$ containing 20 vol $\% \mathrm{H}_{2} \mathrm{O}$ to the Ni electrode, but varying gasses to the LSM electrode, can be used to produce a plot of $\Delta \dot{Z}^{\prime}$ vs $\log (f)$ which gives a measure of the change in the LSM-electrode impedance due to the change from $\mathrm{O}_{2}$ to air. Because the Ni-electrode gas composition is the same for these two EIS, this plot contains no contribution from the Ni-electrode impedance. The plot $\Delta \dot{Z}^{\prime}$ vs $\log (f)$ for the gas changes to the LSM electrode is shown in Fig. 7b, and thus this is an LSM-electrode impedance characteristic for test $\mathrm{B}$ prior to electrolysis testing.

The set of EIS recorded at OCV with varying gas compositions after test $\mathrm{B}_{\mathrm{EL}}$ (Fig. 6b) was used likewise to generate electrode impedance characteristics. These spectra are labelled "after test $\mathrm{B}_{\mathrm{EL}}$ " in Fig. 7. Similar electrode impedance characteristics were made for test $\mathrm{A}$, and the resulting plot of $\Delta \dot{Z}^{\prime}$ vs $\log (f)$ are shown in Fig. 7 . From Fig. 7b, it can be observed that the LSM-electrode impedance characteristics are similar before and after test $\mathrm{B}_{\mathrm{EL}}$. No EIS were recorded to produce an LSM electrode impedance characteristic after tests $\mathrm{A}_{\mathrm{EL}}$. However, the operating conditions at the LSM electrode were similar for tests $\mathrm{A}_{\mathrm{EL}}$ and $\mathrm{B}_{\mathrm{EL}}$, and the LSM electrodes are produced in the exact same way. Therefore, it reasonable to assume that the LSM-electrode impedance characteristic after test $A_{E L}$ is similar to that obtained after test $B_{E L}$, i.e., similar to that obtained prior to electrolysis testing. Also note that the Ni-electrode impedance characteristics before tests $\mathrm{A}_{\mathrm{EL}}$ and $\mathrm{B}_{\mathrm{EL}}$ (Fig. 7a) are quite similar, which shows that the electrode is reproducible.

Furthermore, the noise level for this method of analysis was checked. In Fig. 7, the noise level spectra (or background noise measures) are plots of $\Delta \dot{Z}^{\prime}$ vs $\log (f)$ produced from two EIS recorded with identical operating conditions. The noise-level spectra assure that the features of the obtained electrode impedance characteristics really reflect changes in the electrode impedances due to the changes in gas compositions and not coincidental temporal changes.

\section{Discussion}

First, we discuss whether the performance changes during $A_{E L}$ and $\mathrm{B}_{\mathrm{EL}}$ occur on the LSM electrode or on the Ni electrode. Second, we discuss the in-plane voltage measurements and what they reveal about the distribution of the resistance in the Ni electrode for these tests. Third, we discuss the information that can be retrieved from analysis of the EIS recorded during tests $\mathrm{A}_{\mathrm{EL}}$ and $\mathrm{B}_{\mathrm{EL}}$. Finally, we combine all the information from the measurements to make a sketch of the resistance distribution in the Ni electrode during $\mathrm{B}_{\mathrm{EL}}$.

EIS at OCV: changes in the Ni-electrode performance.- In this subsection, we use EIS at OCV to show that $(i)$ the electrodes are reproducible, (ii) the LSM electrode is unaffected by tests $\mathrm{A}_{\mathrm{EL}}$ and $\mathrm{B}_{\mathrm{EL}}$, and (iii) large changes in the Ni-electrode impedance occur during tests $\mathrm{A}_{\mathrm{EL}}$ and $\mathrm{B}_{\mathrm{EL}}$.

The electrode impedance characteristics obtained at OCV and given by the plot of $\Delta \dot{Z}^{\prime}$ vs $\log (f)$ (Fig. 7) provide valuable electrode-specific information independent of any electric-circuit modelling of the impedance data. In this case study, the plot of $\Delta \dot{Z}^{\prime}$ vs $\log (f)$ reveals that:

1. The four electrode impedance characteristics are very much alike prior to tests $\mathrm{A}_{\mathrm{EL}}$ and $\mathrm{B}_{\mathrm{EL}}$, which implies that the electrodes are reproducible.

2. As noted in the Results section, it is seen from Fig. 7 that the LSM-electrode impedance characteristics are similar before and after test $\mathrm{B}_{\mathrm{EL}}$. This strongly indicates that the LSM electrode is unaffected by test $\mathrm{B}_{\mathrm{EL}}$. Due to the reproducibility of the electrodes and the identical operating conditions for the LSM electrode in tests $\mathrm{A}_{\mathrm{EL}}$ and $\mathrm{B}_{\mathrm{EL}}$, we suppose that the LSM electrode is unaffected by test $A_{E L}$. Hence, the changes in cell voltage and in-plane voltages and EIS were due to changes in the Ni electrode.

3. Large changes in the Ni-electrode impedance occur during 


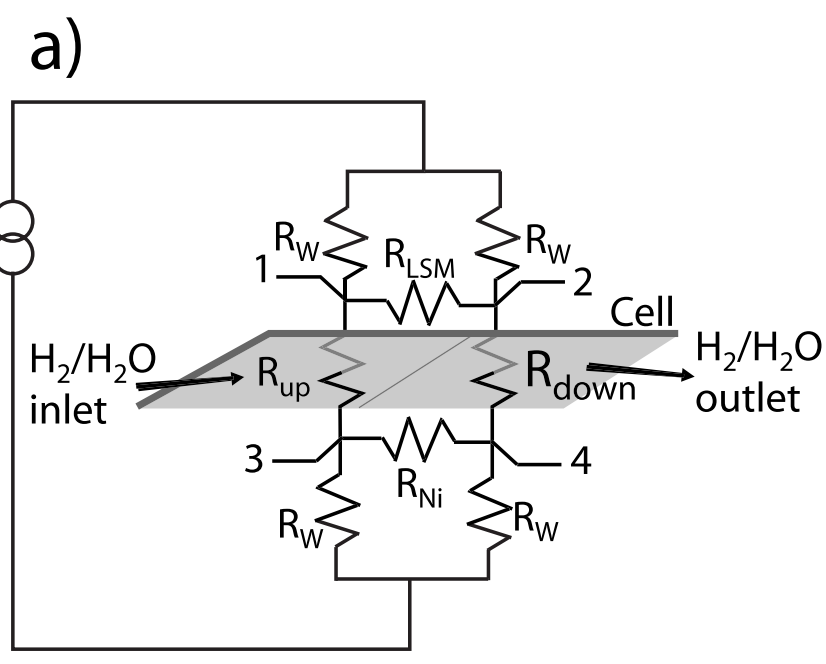

b)

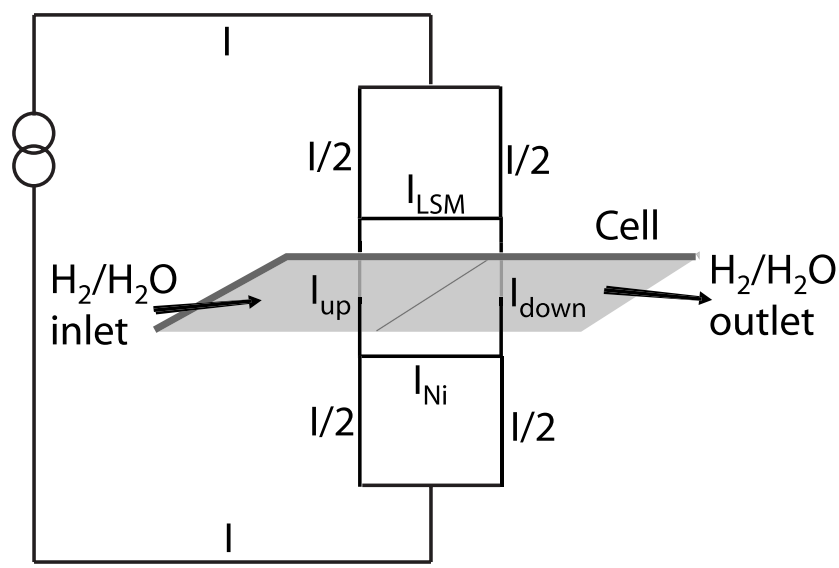

Figure 8. An electric circuit model of the cell test setup shown in Fig. 2. In the model, the cell is divided in an upstream and a downstream part according to the gas-flow direction at the Ni electrode. Points 1, 2, 3, and 4 correspond to the voltage probes presented in Fig. 2b. (a) Resistances in the applied test setup. (b) The current flow through the circuit, given that the inequalities in Eq. 2 are satisfied.

both $\mathrm{A}_{\mathrm{EL}}$ and $\mathrm{B}_{\mathrm{EL}}$. The plot of $\Delta \dot{Z}^{\prime}$ vs $\log (f)$ for test A reveals that a significant loss in performance of the $\mathrm{Ni}$ electrode occurs during the first few days of electrolysis testing. The plot of $\Delta \dot{Z}^{\prime}$ vs $\log (f)$ for test B also implies that the long-term degradation (from point B3 in Fig. 3) is dominated by a loss in performance of the Ni electrode. The cell used for test $\mathrm{B}_{\mathrm{EL}}$ almost fully recovered after the initial passivation (points B1-B3 in Fig. 3), and the observed change in $\Delta \dot{Z}^{\prime}$ vs $\log (f)$ the Ni electrode of test B therefore characterizes this long-term degradation of the cell in test $\mathrm{B}_{\mathrm{EL}}$.

Estimates of resistances in the test setup.- In this subsection, we estimate some resistances in the test setup in order to describe the resistance distributions in the electrodes. Figure 8a shows an electric-circuit model applicable to the cell test setup (Fig. 2). The resistances given in Fig. 8a are as follows: $R_{\mathrm{W}}$ is the resistance in the Pt wires connected to the current-collector foils (Fig. 2b), $R_{\text {up }}$ is the cell resistance of the half part of the cell adjacent to the $\mathrm{Ni}$ electrode gas inlet ("upper half part"), $R_{\text {down }}$ is the cell resistance of the half part of the cell adjacent to the Ni-electrode gas outlet ("lower half part"), $R_{\mathrm{Ni}}$ is the in-plane resistance along the Ni electrode, and $R_{\mathrm{LSM}}$ is the in-plane resistance along the LSM electrode.

First, consider the in-plane resistances $R_{\mathrm{Ni}}$ and $R_{\mathrm{LSM}}$. The gold and nickel current-collector foils are $200 \mu \mathrm{m}$ thick, $4 \mathrm{~cm}$ wide, and $4 \mathrm{~cm}$ long. At $850^{\circ} \mathrm{C}$, the resistivity of $\mathrm{Au}$ is $1 \times 10^{-7} \Omega \mathrm{m}$ and $5 \times 10^{-7} \Omega \mathrm{m}$ for Ni. This gives an in-plane resistance in the $\mathrm{Ni}$ foil of $2.5 \mathrm{~m} \Omega$ and an in-plane resistance in the Au foil of $0.5 \mathrm{~m} \Omega$. Thus, $R_{\mathrm{Ni}}$ and $R_{\mathrm{LSM}}$ are less than 2.5 and $0.5 \mathrm{~m} \Omega$, respectively.

Second, consider the resistance in the platinum wires. The platinum wires (Fig. 2b) have a diameter of $1 \mathrm{~mm}$ and are $\sim 10 \mathrm{~cm}$ long. At $850^{\circ} \mathrm{C}$, the resistivity for $\mathrm{Pt}$ is $4 \times 10^{-7} \Omega \mathrm{m}$, which corresponds to $R_{\mathrm{W}} \approx 40 \mathrm{~m} \Omega$.

Third, consider $R_{\text {up }}$ and $R_{\text {down }}$. Because $R_{\text {up }}$ is the cell resistance of the upstream half part of the cell and $R_{\text {down }}$ is the resistance of the downstream half part of the cell, we have $R_{\text {up }} \approx R_{\text {down }} \approx 2 R_{\text {Cell }}$. From Fig. 4, it is observed that cell resistance is larger than $0.35 \Omega \mathrm{cm}^{2}$, and because the active electrode area is $16 \mathrm{~cm}^{2}, R_{\text {Cell }}$ $>0.35 / 16 \Omega \approx 20 \mathrm{~m} \Omega$. This means that $R_{\text {up }} \approx R_{\text {down }}>40 \mathrm{~m} \Omega$.

We can therefore conclude that the following inequalities are satisfied

$$
R_{\mathrm{W}}, R_{\mathrm{up}}, R_{\mathrm{down}} \gg R_{\mathrm{Ni}}, R_{\mathrm{LSM}}
$$

This inequality is used in the next subsection.

Current distribution in the applied test setup.- In this subsection, we estimate the in-plane currents in the cell electrodes during tests $\mathrm{A}_{\mathrm{EL}}$ and $\mathrm{B}_{\mathrm{EL}}$ and show how the in-plane voltage measurements (Fig. 3b) are related to changes in the Ni-electrode resistance distribution.

We do not expect any significant in-plane currents (and in-plane voltages) along the gas-flow direction at the LSM electrode, because there is no change in the LSM-electrode gas composition during tests $\mathrm{A}_{\mathrm{EL}}$ and $\mathrm{B}_{\mathrm{EL}}$ (the gas is $\mathrm{O}_{2}$ from inlet to outlet of the LSM electrode) and the performance of the LSM electrode seems to be constant during tests $\mathrm{A}_{\mathrm{EL}}$ and $\mathrm{B}_{\mathrm{EL}}$ (see the discussion in the EIS at OCV: changes in the Ni-electrode performance section). Thus, points 1, 2, 3, and 4 in the model in Fig. 8 can be interpreted as the voltage probes shown in Fig. $2 \mathrm{~b}$.

Because $R_{\mathrm{W}}, R_{\text {up }}, R_{\text {down }} \gg R_{\mathrm{Ni}}, R_{\mathrm{LSM}}$, the current-collector foil acts as a shunt and is (almost) an equipotential. This implies that the current through the $\mathrm{Pt}$ wires $\left(R_{\mathrm{W}}\right) \approx I / 2$, where $I$ is the total current through the cell as shown in Fig. 8b. From Kirchoffs first law, it follows that the current to point 1 in Fig. $8 \mathrm{~b}$ is

$$
I / 2-I_{\text {up }}-I_{\mathrm{LSM}}=0
$$

where $I_{\text {up }}$ is the positive current running (during electrolysis testing) toward the half part of the Ni electrode closest to the $\mathrm{H}_{2} \mathrm{O} / \mathrm{H}_{2}$ gas inlet from the half part of the LSM electrode on the other side of the electrolyte. $I_{\mathrm{LSM}}$ is the positive current running from the half part of the LSM electrode closest to the Ni-electrode gas inlet to the half part of the LSM electrode closest to the Ni-electrode gas outlet. (In the model in Fig. 8b, $I_{\text {up }}$ is the positive current running through $R_{\text {up }}$ from point 1 to 3 and $I_{\mathrm{LSM}}$ is the positive current running through $R_{\mathrm{LSM}}$ from point 1 to 2 .)

Likewise, the current to point 3 in Fig. $8 \mathrm{~b}$ is

$$
I_{\text {up }}-I / 2-I_{\mathrm{Ni}}=0
$$

where $I_{\mathrm{Ni}}$ is the positive current running from point 3 to 4 through $R_{\mathrm{Ni}}$. The in-plane voltage along the Ni electrode (Fig. 3b) can be written as $I_{\mathrm{Ni}} R_{\mathrm{Ni}}$ and the in-plane voltage along the LSM electrode as $I_{\mathrm{LSM}} R_{\mathrm{LSM}}$. If we add Eq. 3 to Eq. 4 , we get $I_{\mathrm{LSM}}=-I_{\mathrm{Ni}}$. This means that the correlation between the LSM- and the Ni in-plane voltages observed in Fig. 3b should be explained in terms of changes in $R_{\text {up }}$ and $R_{\text {down }}$, while $R_{\mathrm{Ni}}$ and $R_{\mathrm{LSM}}$ stay constant. 
In-plane voltages and analysis of resistance distribution in the $\mathrm{Ni}$ electrode.- In this subsection, we further describe how the measurements in Fig. 3 relate to changes in the resistance distribution in the $\mathrm{Ni}$ electrode and discuss how the changes could be due to a pollution of the electrode.

The following points need to be considered:

1 . The in-plane voltages are measured along the gas-flow direction at the Ni electrode as shown in Fig. 2b, and the current and gas flow was held constant during tests $\mathrm{A}_{\mathrm{EL}}$ and $\mathrm{B}_{\mathrm{EL}}$.

2. $R_{\mathrm{W}}, R_{\mathrm{up}}, R_{\text {down }} \gg R_{\mathrm{Ni}}, R_{\mathrm{LSM}}$ and points $1,2,3$, and 4 in the model in Fig. 8 may be interpreted as the voltage probes presented in Fig. $2 b$.

3 . When the in-plane voltages are close to zero, the in-plane currents $\left(I_{\mathrm{Ni}}\right.$ and $I_{\mathrm{LSM}}$, Fig. 8$)$ and differences between $R_{\text {up }}$ and $R_{\text {down }}$ are small, whereas large in-plane voltages indicate large $I_{\mathrm{Ni}}$ and $I_{\text {LSM. }}$.

All together, this implies that the changes in the cell voltage and the in-plane voltages observed in Fig. 3 must be due to changes in $R_{\text {up }}$ and $R_{\text {down }}$, i.e., it must be due to changes in the resistance distribution parallel to the gas-flow direction at the Ni electrode.

From the measured in-plane voltages (Fig. 3) and the previously calculated in-plane resistances $R_{\mathrm{Ni}}$ and $\mathrm{R}_{\mathrm{LSM}}$, it is possible to estimate the in-plane currents $\left(I_{\mathrm{Ni}}\right.$ and $I_{\mathrm{LSM}}$, Fig. 8). These in-plane currents never went higher than $10 \%$ of the total current through the cell. This means that $R_{\text {up }}$ and $R_{\text {down }}$ are quite alike in magnitude at all times, and this in turn means that the changes in the resistance distribution parallel to the gas-flow direction at the Ni electrode are limited. So, even though the steam partial pressure is higher at the $\mathrm{Ni}$ electrode gas inlet, relative to the outlet, the constant flow of gas at the $\mathrm{Ni}$ electrode assures that the resistance stays fairly welldistributed along the gas-flow direction, i.e., that the differences between $R_{\text {up }}$ and $R_{\text {down }}$ are relatively small. In contrast, great changes are observed in the resistance distribution perpendicular to the gas-flow direction at the $\mathrm{Ni}$ electrode become quite high, in accordance with Fig. 5 (see the following section).

Another test with identical test conditions as test $\mathrm{B}_{\mathrm{EL}}$ was conducted with an Au seal instead of a glass seal. ${ }^{34}$ The cell voltage curve for this test showed an almost linear increase (similar to the last $\sim 600 \mathrm{~h}$ of test $\mathrm{B}_{\mathrm{El}}$ ), i.e., the passivation/activation as observed for test $B_{E L}$ was eliminated by substituting the albite glass seal with $\mathrm{Au}$. This suggests that it is impurities from the glass seal that pollute the $\mathrm{Ni} / \mathrm{YSZ}$ electrode and cause the decrease in the electrode performance in $\mathrm{A}_{\mathrm{EL}}$ and start of $\mathrm{B}_{\mathrm{EL}}$.

For tests $\mathrm{A}_{\mathrm{EL}}$ and $\mathrm{B}_{\mathrm{EL}}$, the in-plane voltages had a characteristic and reproducible behavior. During the electrolysis tests, the steam partial pressure is highest at the half-part of the Ni electrode closest to the gas inlet, relative to the half-part closest to the gas outlet. The contamination with vapor-phase impurities from the glass seal (e.g., Si hydroxide species) have the highest partial pressure at the $\mathrm{H}_{2} \mathrm{O} / \mathrm{H}_{2}$ inlet part of the $\mathrm{Ni}$ electrode, therefore causing the highest impurity deposition rate at this part of the electrode. ${ }^{32,34}$ This increases $R_{\text {up }}$ relative to $R_{\text {down }}$, which we can observe as the increase in the LSM in-plane voltage accompanied with the decrease in the $\mathrm{Ni}$ in-plane voltage over the first approximately 5 days of electrolysis testing. Imagine that over time the part of the $\mathrm{Ni}$ electrode closest to the gas outlet also gets contaminated with impurities. This causes an increase in $R_{\text {down }}$ relative to $R_{\text {up }}$, i.e., a decrease in the LSM in-plane voltage accompanied with an increase in the $\mathrm{Ni}$ in-plane voltage, just as we observe for tests $A_{E L}$ and $B_{E L}$ in Fig. $3 b$ over the following 5 days of electrolysis testing. At this point, the cell voltage reaches a maximum, i.e., maximum loss in performance of the cells. Now, following the development of the cell voltage curve for test $\mathrm{B}_{\mathrm{EL}}$, it is clear that the cell activates again at constant electrolysis conditions (from B2 to B3 in Fig. 3a), indicating that more and of the more active sites become available again. During this activation of the cell, it is observed that the in-plane voltages pass through extreme values, just as it was observed during the passivation of both tests $A_{E L}$ and $B_{E L}$ over the first few days of electrolysis testing. Therefore, the in-plane voltages measured dur-

\begin{tabular}{|c|c|c|c|}
\hline $\begin{array}{l}\text { Impedance } \\
\text { Spectrum }\end{array}$ & $\begin{array}{c}f_{\mathrm{s}} \\
(\mathrm{Hz})\end{array}$ & $\begin{array}{l}-2 Z^{\prime \prime}\left(f_{\mathrm{s}}\right) \\
\left(\mathrm{m} \Omega \mathrm{cm}^{2}\right)\end{array}$ & $\begin{array}{c}R_{\text {Conv }}^{\text {IS }} \\
\left(\mathrm{m} \Omega \mathrm{cm}^{2}\right)\end{array}$ \\
\hline A1 & 1 & 96 & 101 \\
\hline B1 & 4 & 51 & 27 \\
\hline
\end{tabular}

ing the activation of the cell in test $\mathrm{B}_{\mathrm{EL}}$ show that the activation of the cell does not occur evenly distributed over the cell with time but more as a "wave" across the cell, where one part of the cell activates most to begin with and the activation of other part follows over time.

The results presented here were used as "input" for the scanning electron microscopy, transmission electron microscopy (TEM)/ scanning TEM, and energy dispersive spectroscopy work on pieces of the cell used for test $\mathrm{B}_{\mathrm{EL}}$, where Si-containing impurities were found at triple-phase boundaries in the Ni electrode. ${ }^{33}$

EIS during electrolysis testing.- In this subsection, we derive the gas-conversion resistance in a plug-flow setup and relate the changes with time of the low-frequency impedance arcs in Fig. 4 to changes in the distribution of resistance in the Ni electrode. The analysis shows that an uneven resistance distribution builds up perpendicular to the gas-flow direction at the $\mathrm{Ni}$ electrode.

Primdahl and co-workers have studied the $\mathrm{Ni}$ electrode in a three-electrode setup. ${ }^{38}$ The electrode was examined in a $\mathrm{H}_{2} / \mathrm{H}_{2} \mathrm{O}$ gas, and a low-frequency impedance arc with summit frequency around $1 \mathrm{~Hz}$ was assigned to gas conversion. Barfod and co-workers have tested cells similar to those tested in this work but in fuel cell test mode and using a similar setup as the one described in Fig. $2 .^{24}$ Barfod et al. also observed a low-frequency arc with a summit frequency around $1 \mathrm{~Hz}$ and showed that this was due to gas-conversion resistance at the $\mathrm{Ni}$ electrode. The observed development of the low-frequency arc of the EIS during tests $\mathrm{A}_{\mathrm{EL}}$ and $\mathrm{B}_{\mathrm{EL}}$ is therefore analyzed in the context of "gas-conversion resistance."

The expression for the gas-conversion resistance in a plug-flow setup measured under current load is derived in the Appendix and is given as

$$
R_{\text {Conv }}=\frac{R T}{8 J_{\mathrm{i}} F^{2}}\left(\frac{1}{x_{\mathrm{H}_{2}}^{\text {in }}}+\frac{1}{x_{\mathrm{H}_{2} \mathrm{O}}^{\text {in }}}\right)
$$

where $R$ is the ideal gas constant, $T$ is the temperature in Kelvin, $F$ is Faraday's constant, $x_{\mathrm{H}_{2}}^{\text {in }}$ and $x_{\mathrm{H}_{2} \mathrm{O}}^{\text {in }}$ are the molar fractions of $\mathrm{H}_{2}$ and $\mathrm{H}_{2} \mathrm{O}$ in the inlet gas to the $\mathrm{Ni}$ electrode, and $J_{\mathrm{i}}$ is the area-specific molar flux to the cell. The conversion resistance measured by impedance spectroscopy, $R_{\text {Conv }}^{\mathrm{IS}}$, is also derived in the Appendix. $R_{\mathrm{Conv}}^{\mathrm{IS}}$ is calculated for $\mathrm{A}_{\mathrm{EL}}$ and $\mathrm{B}_{\mathrm{EL}}$ and shown in Table II. The calculation is based on the operating conditions in Table I. For spectrum A1 (Fig. 4), the low-frequency arc is almost a perfect semicircle, i.e., having a frequency exponent close to unity, which means that the resistance associated with the process causing the low-frequency arc can be measured as $-2 Z^{\prime \prime}\left(f_{\mathrm{s}}\right)$, that is, $-2 Z^{\prime \prime}(1 \mathrm{~Hz})=96 \mathrm{~m} \Omega \mathrm{cm}^{2}$. For test $\mathrm{A}_{\mathrm{EL}}$, the gas-conversion resistance, $R_{\mathrm{Conv}}^{\mathrm{IS}}$, was calculated to be $101 \mathrm{~m} \Omega \mathrm{cm}^{2}$ from the known inputs (Table I and the Appendix), and it is clear that gas conversion in the Ni electrode dominates the low-frequency arc of spectrum A1. The low frequency arc more than doubles in magnitude for test $\mathrm{A}_{\mathrm{EL}}$ over time (Fig. 4a and 5), but at the same time the summit frequency stays constant at $1 \mathrm{~Hz}$. For spectrum B1 the gas-conversion resistance dominates the lowfrequency arc (Table II), even though other processes (i.e., gas diffusion $^{24,39}$ ) are observed to contribute to the arc. Also, in test $\mathrm{B}_{\mathrm{EL}}$ the low-frequency arc increases (and subsequently decreases) at constant summit frequency (Fig. 4b and 5). 
To interpret these observations, suppose the fuel cell is a parallel connection of two half parts along the gas-flow direction at the $\mathrm{Ni}$ electrode, as in Fig. 8. Now, if the upstream (or downstream) part of the Ni electrode stops working, all the gas conversion takes place at the downstream (or upstream) part. This decreases the capacity of gas conversion by approximately a factor of two (because the volume above the active part of the electrode is reduced by a factor of two). In contrast, it does not affect the gas-conversion resistance, because the average change in the Nernst potential, $\bar{\eta}$, at the active part of the electrode is unchanged (see the Appendix for details). Thus, we can conclude that an uneven resistance distribution along the gas-flow direction at the $\mathrm{Ni}$ electrode preserves the size but increases the summit frequency of the gas-conversion arc. This is not in accordance with the observations for the gas-conversion arc in Fig. 4 and 5.

Now, suppose the fuel cell is a parallel connection of two half parts across the gas-flow direction at the $\mathrm{Ni}$ electrode. If one of these half parts stops working, this also decreases the capacity of gas conversion by approximately a factor of two (again, because the volume above the active part of the electrode is reduced by a factor of two). Moreover, the resistance of the gas conversion increases by approximately a factor of two, because the average change in the Nernst potential, $\bar{\eta}$, at the active part of the electrode increases by a factor of two. Thus, we can conclude that an uneven resistance distribution across the gas-flow direction at the $\mathrm{Ni}$ electrode increases the size but preserves the summit frequency of the gasconversion arc. This suggests that the observation of the gasconversion arc in Fig. 4 and 5 is due to an uneven resistance distribution perpendicular to the gas-flow direction at the $\mathrm{Ni}$ electrode.

A detailed analysis of the evolution of the low-frequency impedance arc in test $\mathrm{A}_{\mathrm{EL}}$ and how it provides information about the resistance distribution in the $\mathrm{Ni}$ electrode is given elsewhere. ${ }^{40}$ The analysis is based on an expression of the combined gas-conversion and gas-diffusion impedance in a plug-flow setup, recently derived by Jacobsen et al. ${ }^{39}$

Analysis combining cell voltage, in-plane voltage differences, and EIS. - In this subsection, we discuss the advantages of combining complementary measurement techniques. The cell voltage provides a measure of the performance of the entire cell and gives easily accessible data and an overview for comparison with other cell tests, but cell voltage measurements lack the possibility of giving electrode-specific information or revealing unevenness in the distribution of resistances in the electrodes. The EIS measured at OCV with different gas compositions before and after a cell test can be used to make model-independent and electrode-specific impedance characteristics (Fig. 7). The two cases shown in this paper indicate that it is the Ni electrode that is affected by $\mathrm{A}_{\mathrm{EL}}$ and $\mathrm{B}_{\mathrm{EL}}$. Supplementing the cell test setup with in-plane voltages measurements provides information about the distribution of resistances (and currents) along the electrodes and can reveal how such resistance distributions change during testing, as illustrated for tests $\mathrm{A}_{\mathrm{EL}}$ and $B_{E L}$. An improved probing could be obtained by an increased number of probes for in-plane voltage measurements. The EIS recorded during tests $\mathrm{A}_{\mathrm{EL}}$ and $\mathrm{B}_{\mathrm{EL}}$ gave not only a second measure of the entire cell performance under current load but also a possibility to obtain information about the evolution of the inequalities in resistance distribution in the Ni electrode during tests $\mathrm{A}_{\mathrm{EL}}$ and $\mathrm{B}_{\mathrm{EL}}$. Combined with the fact that it is the glass sealing that causes the passivation/activation of the $\mathrm{Ni}$ electrode in the first part of $\mathrm{B}_{\mathrm{EL}},{ }^{33,34}$ we sketch how the resistance distribution evolves during the first part of $\mathrm{B}_{\mathrm{EL}}$ in Fig. 9. In total, the four different sets of data for tests $A_{E L}$ and $B_{E L}$ have provided electrode-specific details on the loss of performance of the cells during electrolysis testing, and this study has given valuable input for postmortem analysis of the tested cells and revealed a problem with the applied glass sealing. ${ }^{33,34}$ Tests $A_{E L}$ and $\mathrm{B}_{\mathrm{EL}}$ can be considered special cases showing a particular passivation process for electrolysis testing of SOCs. However, seen in a

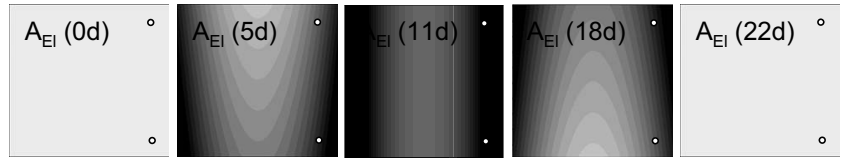

Figure 9. Sketch of the passivation pattern of the Ni electrode in test $\mathrm{B}_{\mathrm{El}}$ at different times after onset of the electrolysis operation given in days (d), see Fig. 3. The dots mark voltage probes 3 and 4 in Fig. 2 and 8. The upstream part of the Ni electrode is at the bottom of the five drawings.

broader perspective, such an advanced cell test setup provides sets of complementary data that can "break the code" in the work of understanding the different losses in performance for the often complex full cell testing.

\section{Conclusion}

In this work, we reported on the use of an advanced and extensively instrumentated test setup for testing of full solid oxide cells in a plug flow. A case study of two steam electrolysis tests $\left(\mathrm{A}_{\mathrm{EL}}\right.$ and $\mathrm{B}_{\mathrm{EL}}$ ) was chosen to illustrate the strength of combining measurements of cell voltage, in-plane voltages, and EIS under current load and at OCV. This enabled a detailed analysis of the loss of performance for the cells during electrolysis testing. From the obtained data from two electrolysis tests, we can conclude that:

1. Cell voltage measurements showed that the cells passivated over the first $\sim 10$ days of electrolysis testing. Test $\mathrm{A}_{\mathrm{EL}}$ was stopped after $\sim 10$ days. Test $B_{\mathrm{EL}}$ activated again over the following 10 days, and a long-term degradation became dominant.

2. In-plane voltage measurements provided information on the resistance distribution across the electrodes and revealed changes in the resistance distribution parallel to the gas flow in the Ni electrode. However, the changes are relatively small compared with the changes perpendicular to the gas flow. This was shown by the analysis of the low-frequency arc in the impedance spectra recorded during electrolysis operation.

3. The development of the cell voltage and in-plane voltages indicates that the passivation of the cells (and activation for test $\mathrm{B}_{\mathrm{EL}}$ ) occurs as a "wave" across the cell, e.g., of contamination with impurities, and does not build up evenly distributed across the cell over time.

4. EIS during electrolysis showed almost constant series resistances but varying polarization resistances for both tests. Analysis of the low-frequency arc $(1-4 \mathrm{~Hz})$ indicates that gas-conversion impedance contributions dominate this arc, but gas-diffusion impedance contributions are present as well.

5. Electrode-impedance characterization at OCV showed reproducibility of the electrodes.

6. The impedance characterization also revealed that the $\mathrm{Ni}$ electrode performance loss by far dominated the performance loss in test $\mathrm{B}_{\mathrm{EL}}$ and most likely also in test $\mathrm{A}_{\mathrm{EL}}$.

7. An expression of the gas-conversion resistance in a plug-flow setup was derived. The gas-conversion resistance was found to be approximately equal to half the gas-conversion resistance in a continuously stirred tank reactor (CSTR) model.

8. Combination of measured cell voltages, in-plane voltages, and EIS under current load and at OCV provided optimal sets of complementary data for thorough analysis of the two electrolysis tests in this case study. This illustrated the strength of an advanced and extensively instrumented test setup for full cell testing.

\section{Acknowledgments}

The authors thank co-workers at the Fuel Cell and Solid State Chemistry Division at Risø National Laboratory for Sustainable Energy, The Technical University of Denmark. This work was supported financially by Programme Commission on Sustainable Energy and Environment, The Danish Council for Strategic Research, via the SERC project (www.serc.dk), contract no. 2104-06-0011. 

article.

Ris $\phi$ National Laboratory assisted in meeting the publication costs of this

\section{Appendix}

\section{Derivation of $R_{\text {Conv }}$ in a Plug-Flow Setup}

The cell voltage at OCV (no current through the cell) depends on the gas compositions via the Nernst equation

$$
E=E^{\mathrm{o}}+\frac{R T}{2 F} \ln \frac{P_{\mathrm{H}_{2} \mathrm{O}}^{\text {in }}}{P_{\mathrm{H}_{2}}^{\text {in }} \sqrt{P_{\mathrm{O}_{2}}^{\text {in }}}}
$$

where $E$ is the Nernst potential, $E^{\circ}$ is the standard potential, $R$ is the ideal gas constant, $T$ is the temperature in Kelvin, and $F$ is Faraday's constant. $P_{\mathrm{H}_{2} \mathrm{O}}^{\text {in }}$ and $P_{\mathrm{H}_{2}}^{\text {in }}$ are the partial pressures of $\mathrm{H}_{2} \mathrm{O}$ and $\mathrm{H}_{2}$ in the inlet gas to the Ni electrode, and $P_{\mathrm{O}_{2}}^{\text {in }}$ is the partial pressure of $\mathrm{O}_{2}$ in the inlet gas to the LSM electrode. The gas compositions changes along the gas-flow directions when the cell is operated as a fuel cell or as an electrolyzer cell. This changes the Nernst potential according to Eq. 5, neglecting changes in the gas composition on the air side. The change in the Nernst potential due to the change in gas compositions at the $\mathrm{Ni}$ electrode at the position $z$ along the gas-flow direction can be written as

$$
\eta(z)=E^{\mathrm{o}}-\frac{R T}{n F} \ln \frac{P_{\mathrm{H}_{2} \mathrm{O}}(z)}{P_{\mathrm{H}_{2}}(z)}-\left(E^{\mathrm{o}}-\frac{R T}{n F} \ln \frac{P_{\mathrm{H}_{2} \mathrm{O}}^{\mathrm{in}}}{P_{\mathrm{H}_{2}}^{\text {in }}}\right)
$$

Where $P_{\mathrm{H}_{2} \mathrm{O}}(z)$ and $P_{\mathrm{H}_{2}}(z)$ are the gas compositions at the position $z$ with $P_{\mathrm{H}_{2} \mathrm{O}}(0)$ $=P_{\mathrm{H}_{2} \mathrm{O}}^{\text {in }}$ and $P_{\mathrm{H}_{2}}(0)=P_{\mathrm{H}_{2}}^{\mathrm{in}}$. The average change in the Nernst potential can then be found as

$$
\bar{\eta}=\frac{R T}{2 F l} \int_{0}^{l} \ln \frac{P_{\mathrm{H}_{2} \mathrm{O}}^{\text {in }}}{P_{\mathrm{H}_{2}}^{\text {in }}}-\ln \frac{P_{\mathrm{H}_{2} \mathrm{O}}(z)}{P_{\mathrm{H}_{2}}(z)} d z
$$

where $l$ is the length of the Ni electrode along the gas-flow direction. If we assume the current density, $i$, to be uniform (i.e., that $i$ does not depend on $z$ ), we can write the molar fractions of $\mathrm{H}_{2} \mathrm{O}$ and $\mathrm{H}_{2}$ at the position $z$ as

$$
\begin{gathered}
x_{\mathrm{H}_{2} \mathrm{O}}(z)=\frac{P_{\mathrm{H}_{2} \mathrm{O}}(z)}{P_{\text {total }}}=x_{\mathrm{H}_{2} \mathrm{O}}^{\text {in }}+\frac{z b i}{2 F \dot{N}} \\
x_{\mathrm{H}_{2}}(z)=\frac{P_{\mathrm{H}_{2}}(z)}{P_{\text {total }}}=x_{\mathrm{H}_{2}}^{\text {in }}-\frac{z b i}{2 F \dot{N}}
\end{gathered}
$$

where $P_{\text {total }}$ is the total pressure, $x_{\mathrm{H}_{2} \mathrm{O}}^{\text {in }}$ is the molar fraction of $\mathrm{H}_{2} \mathrm{O}$ in the inlet gas to the Ni electrode, $x_{\mathrm{H}_{2}}^{\text {in }}$ is the molar fraction of $\mathrm{H}_{2}$ in the inlet gas to the Ni electrode, $\dot{N}$ is the molar flux of $\mathrm{H}_{2}$ and $\mathrm{H}_{2} \mathrm{O}$ to the Ni electrode, $b$ is the width of the Ni electrode perpendicular to the gas-flow direction equation, and $i$ is the current density. Substituting equation into and solving the integral, we get

$$
\begin{aligned}
\bar{\eta}= & \frac{R T}{2 F}\left\{\ln \left(\frac{x_{\mathrm{H}_{2} \mathrm{O}}^{\text {in }}}{x_{\mathrm{H}_{2}}^{\text {in }}}\right)-\ln \left(\frac{x_{\mathrm{H}_{2} \mathrm{O}}^{\text {in }}+\Delta x}{x_{\mathrm{H}_{2}}^{\text {in }}-\Delta x}\right)-\frac{x_{\mathrm{H}_{2} \mathrm{O}}^{\text {in }}}{\Delta x} \ln \left(\frac{x_{\mathrm{H}_{2} \mathrm{O}}^{\text {in }}+\Delta x}{x_{\mathrm{H}_{2} \mathrm{O}}^{\text {in }}}\right)\right. \\
& \left.-\frac{x_{\mathrm{H}_{2}}^{\text {in }}}{\Delta x} \ln \left(\frac{x_{\mathrm{H}_{2}}^{\text {in }}-\Delta x}{x_{\mathrm{H}_{2}}^{\text {in }}}\right)\right\}
\end{aligned}
$$

where $\Delta x=\Delta x_{\mathrm{H}_{2} \mathrm{O}}=x_{\mathrm{H}_{2} \mathrm{O}}^{\text {in }}-x_{\mathrm{H}_{2} \mathrm{O}}^{\text {out }}=-\Delta x_{\mathrm{H}_{2}}=x_{\mathrm{H}_{2}}^{\text {out }}-x_{\mathrm{H}_{2}}^{\text {in }}=i b l / 2 F \dot{N}$ and $x_{\mathrm{H}_{2} \mathrm{O}}^{\text {out }}$ and $x_{\mathrm{H}_{2}}^{\text {out }}$ are the molar fractions of $\mathrm{H}_{2} \mathrm{O}$ and $\mathrm{H}_{2}$, respectively, in the outlet gas. When $\Delta x$ $\ll x_{\mathrm{H}_{2} \mathrm{O}}^{\text {in }}$ and $\Delta x \ll x_{\mathrm{H}_{2}}^{\text {in }}$, we can linearize Eq. A-5 using the Taylor expansion $\ln (1$ $+y)=y-\frac{1}{2} y^{2}$ for $y \ll 1$ to give

$$
\bar{\eta}=-\frac{R T}{4 F}\left(\frac{\Delta x}{x_{\mathrm{H}_{2}}^{\text {in }}}+\frac{\Delta x}{x_{\mathrm{H}_{2} \mathrm{O}}^{\text {in }}}\right)
$$

The resistance can then be found as

$$
R_{\text {Conv }}=-\frac{\bar{\eta}}{i}=\frac{R T b l}{8 \dot{N} F^{2}}\left(\frac{1}{x_{\mathrm{H}_{2}}^{\mathrm{in}}}+\frac{1}{x_{\mathrm{H}_{2} \mathrm{O}}^{\mathrm{in}}}\right)=\frac{R T}{8 J_{i} F^{2}}\left(\frac{1}{x_{\mathrm{H}_{2}}^{\mathrm{in}}}+\frac{1}{x_{\mathrm{H}_{2} \mathrm{O}}^{\mathrm{in}}}\right)
$$

where $J_{\mathrm{i}}=\dot{N} / b l$ is the area-specific molar flux to the cell. $R_{\text {Conv }}$ is seen to be half the gas-conversion resistance in a CSTR setup. ${ }^{38}$ When $\Delta x \ll x_{\mathrm{H}_{2} \mathrm{O}}^{\text {in }}$ and $\Delta x \ll x_{\mathrm{H}_{2}}^{\text {in }}$ is not satisfied, the gas-conversion resistance measured under current load by impedance spectroscopy, $R_{\text {Conv }}^{\mathrm{IS}}$, deviates from $R_{\text {Conv }}$. This is because the impedance current is a small perturbation of the large dc current, i.e., $R_{\mathrm{Conv}}^{\mathrm{IS}}=\partial \bar{\eta} /\left.\partial i\right|_{\mathrm{i}}$. Taking the derivative of Eq. A-7 with respect to $i$ yields

$$
R_{\mathrm{Conv}}^{\mathrm{IS}}=\frac{R T b l}{4 \dot{N} F^{2}}\left\{\frac{x_{\mathrm{H}_{2} \mathrm{O}}^{\text {in }}}{\Delta x^{2}} \ln \left(\frac{x_{\mathrm{H}_{2} \mathrm{O}}^{\text {in }}+\Delta x}{x_{\mathrm{H}_{2} \mathrm{O}}^{\text {in }}}\right)+\frac{x_{\mathrm{H}_{2}}^{\text {in }}}{\Delta x^{2}} \ln \left(\frac{x_{\mathrm{H}_{2}}^{\text {in }}-\Delta x}{x_{\mathrm{H}_{2}}^{\text {in }}}\right)\right\}
$$

\section{References}

1. R. M. Ormerod, Chem. Soc. Rev., 32, 17 (2003).

2. S. M. Haile, Acta Mater, 51, 5981 (2003).

3. J. M. Ralph, A. C. Schoeler, and M. Krumpelt, J. Mater. Sci., 36, 1161 (2001).

4. S. C. Singhal, Solid State Ionics 135, 305 (2000).

5. S. C. Singhal and K. Kendall, High Temperature Solid Oxide Fuel Cells: Fundamentals, Design, and Applications, Elsevier, Oxford (2004).

6. A. Lashtabeg and S. J. Skinner, J. Mater. Chem., 16, 3161 (2006).

7. F. Tietz, H. P. Buchkremer, and D. Stover, J. Electroceram., 17, 701 (2006).

8. A. Hagen, R. Barfod, P. V. Hendriksen, Y. L. Liu, and S. Ramousse, J. Electrochem. Soc., 153, A1165 (2006)

9. S. C. Singhal, Solid State Ionics, 152, 405 (2002).

10. W. S. Wang, Y. Y. Huang, S. W. Jung, J. M. Vohs, and R. J. Gorte, J. Electrochem. Soc., 153, A2066 (2006).

11. J. S. Herring, J. E. O'Brien, C. M. Stoots, G. L. Hawkes, J. J. Hartvigsen, and M. Shahnam, Int. J. Hydrogen Energy, 32, 440 (2007).

12. J. Udagawa, P. Aguiar, and N. P. Brandon, J. Power Sources, 166, 127 (2007).

13. N. N. Osada, H. Uchida, and M. Watanabe, J. Electrochem. Soc., 153, A816 (2006).

14. R. Hino, K. Haga, H. Aita, and K. Sekita, Nucl. Eng. Des., 233, 363 (2004).

15. H. S. Hong, U. S. Chae, S. T. Choo, and K. S. Lee, J. Power Sources, 149, 84 (2005).

16. B. Zhu, I. Albinsson, C. Andersson, K. Borsand, M. Nilsson, and B. E. Mellander, Electrochem. Commun., 8, 495 (2006).

17. A. Hauch, S. H. Jensen, M. Mogensen, and S. Ramousse, J. Electrochem. Soc., 153, A1741 (2006).

18. A. Hauch, S. D. Ebbesen, S. H. Jensen, and M. Mogensen, J. Mater. Chem., 18, 2331 (2008).

19. S. H. Jensen, P. H. Larsen, and M. Mogensen, Int. J. Hydrogen Energy, 32, 3253 (2007).

20. J. Hartvigsen, S. Elangovan, J. E. O'Brien, C. Stoots, and J. Herring, ECS Trans., 7(1), 357 (2007)

21. J. E. O'Brien, C. M. Stoots, J. S. Herring, and J. Hartvigsen, J. Fuel Cell Sci. Technol., 3, 213 (2006)

22. S. Linderoth, P. H. Larsen, M. Mogensen, P. V. Hendriksen, N. Christiansen, and H. Holm-Larsen, Mater. Sci. Forum, 539, 1309 (2007).

23. B. C. H. Steele and A. Heinzel, Nature (London), 414, 345 (2001).

24. R. Barfod, M. Mogensen, T. Klemens $\varnothing$, A. Hagen, Y. L. Liu, and P. V. Hendriksen, J. Electrochem. Soc., 154, B371 (2007).

25. P. Holtappels, I. C. Vinke, L. G. J. de Haart, and U. Stimming, J. Electrochem. Soc., 146, 2976 (1999).

26. S. Primdahl and M. Mogensen, J. Electrochem. Soc., 145, 2431 (1998).

27. S. Primdahl and M. Mogensen, J. Electrochem. Soc., 146, 2827 (1999).

28. M. J. Jørgensen, S. Primdahl, and M. Mogensen, Electrochim. Acta, 44, 4195 (1999).

29. R. Barfod, M. Mogensen, T. Klemenso, A. Hagen, Y. L. Liu, and P. V. Hendriksen, J. Electrochem. Soc., 154, B371 (2007).

30. Q. A. Huang, R. Hui, B. W. Wang, and H. J. Zhang, Electrochim. Acta, 52, 814 (2007).

31. S. H. Jensen, A. Hauch, P. V. Hendriksen, M. Mogensen, N. Bonanos, and T. Jacobsen, J. Electrochem. Soc., 154, B1325 (2007).

32. A. Hauch, S. H. Jensen, M. Mogensen, and J. B. Bilde-Sørensen, J. Electrochem Soc., 154, A619 (2007).

33. A. Hauch, J. R. Bowen, L. T. Kuhn, and M. Mogensen, Electrochem. Solid-State Lett., 11, B38 (2008)

34. A. Hauch, S. D. Ebbesen, S. H. Jensen, and M. Mogensen, J. Electrochem. Soc 155, B1184 (2008)

35. P. H. Larsen, C. Bagger, S. Linderoth, M. Mogensen, S. Primdahl, M. J. Jorgensen, P. V. Hendriksen, B. Kindl, N. Bonanos, F. W. Poulsen et al., in SOFC VII, H. Yokokawa and S. C. Singhal, Editors, PV 01-16, p. 28, The Electrochemical Society Proceedings Series, Pennington, NJ (2001).

36. N. Bonanos, B. C. H. Steele, and E. P. Butler, in Impedance Spectroscopy: Theory, Experiment, and Applications, E. Barsoukov and J. R. Macdonald, Editors, p. 205 , John Wiley \& Sons, Hoboken, NJ (2005).

37. S. H. Jensen, Ph.D. Thesis, Technical University of Denmark, Roskilde (2006); http://www.risoe.dk/rispubl/ABF/abfpdf/ris-phd-29.pdf

38. S. Primdahl and M. Mogensen, J. Electrochem. Soc., 145, 2431 (1998).

39. T. Jacobsen, P. V. Hendriksen, and S. Koch, Electrochim. Acta, 53, 7500 (2008).

40. S. H. Jensen, P. V. Hendriksen, M. Mogensen, and T. Jacobsen, ECS Trans., 3(26), 307 (2008). 